\title{
FROM SCIENCE PROGRAM CONVENERS TO SCIENCE PROGRAM DEVELOPERS: AN ONLINE PROFESSIONAL DEVELOPMENT PROGRAM FOR RURAL LIBRARIANS
}

\section{Karen Brown, 1 Karen Gareis, 2 Meighan Maloney, 3 \& Daniel Rockmore4,*}

1 School of Information Studies, Dominican University, River Forest, Illinois 60305, USA

2 Goodman Research Group, Cambridge, Massachusetts 02139, USA

3 Dawson Media Group, Portland, Oregon 97206, USA

4 Department of Mathematics, Dartmouth College, Hanover, New Hampshire 03755, USA

*Address all correspondence to: Daniel Rockmore, Department of Mathematics, Dartmouth College, Hanover NH 03755, E-mail: dnrockmore@gmail.com

\begin{abstract}
Pushing the Limits is an NSF-funded project designed to bring accessible STEM-based programming to adult audiences in rural communities as well as enhance the self-efficacy of the resident librarians as informal science learning (ISL) facilitators. The program uses a scaffolded system of support to help move the librarians from the role of "convener" to "developer" of ISL programming. Online professional development is key to the success of the program with over three-quarters of the participating librarians finding that online videos were crucial to their progress. In this paper we discuss and present some initial findings around the project's use of online environments for enabling this successful nationwide program and discuss some of the broader potential and implications of these findings.
\end{abstract}

KEY WORDS: scaffolded learning, professional development, librarian, informal science learning, rural libraries

\section{INTRODUCTION}

The emergence of public programs and projects designed to promote an understanding of STEM has been rapid and extensive throughout North America over the past decade. The primary focus, however, has tended to be on children and teens. This paper describes Pushing the Limits (PTL), a public programming initiative that is unique in that it focuses on 
adults in rural communities. The initiative, funded in part by the National Science Foundation (NSF), specifically targets adults in rural communities, while building the capacity of public libraries to serve as community hubs for STEM learning. The development of online learning and digital resources are essential components of the project, providing a common platform for librarians and scientists across the country as they participate in professional development experiences and design their own locally based programs.

Through two grant-funded projects, $\uparrow$ Pushing the Limits has (to date) reached 194 rural communities across the United States, representing 43 states. In each community, the public library serves as the venue for the programs. As highlighted in 2015 at the Public Libraries and Science: A National Conference on Current Trends and Future Directions (NSF, 2015) and in the American Library Association's annual State of America's Libraries report (ALA, 2017), public libraries have increasingly expanded their services and public programs to engage communities around science topics and issues. With Pushing the Limits, a public librarian and scientist co-host a program series, which combines engaging readings, videos, and lively discussions to encourage understanding of STEM topics and issues.

But, the goals of PTL go beyond providing materials to convene a fixed set of library programs. More importantly, PTL also aims to develop rural librarians' self-efficacy as community-embedded informal STEM learning (ISL) facilitators and program developers. Self-efficacy may be defined as "the extent or strength of one's belief in one's own ability to complete tasks and reach goals" (see Verbeke et al., in press). The role of self-efficacy, particularly in the facilitation of science learning, has been extensively studied in formal education (e.g., Bandura, 2006; Gibson and Dembo, 1984; McKinnon and Lamberts, 2013; Riggs and Enochs, 1990; Tschannen-Moran and Hoy, 2001; Tschannen-Moran et al., 1998).

To encourage self-efficacy the project uses a sequenced or scaffolded learning (Palincsar, 1986; Beed et al., 1991) that starts with foundational professional development aligned with a fully supported library program "in-a-box" for librarians to share with adults in their community. Beginning with ongoing communication with project staff and access to multiple program resources, the librarians progress through stages of progressively reduced support, as they are first encouraged to work with their science partners to customize components of the PTL programs, and then continue to work with their science partner to co-develop full ISL programs for adults. The steps in the PTL program are outlined in Table 1. 
TABLE 1: Steps in the PTL scaffolded learning process

\begin{tabular}{|c|c|c|c|}
\hline & Focus & Activity & Continuum \\
\hline 1 & $\begin{array}{l}\text { Skills-based } \\
\text { Learning }\end{array}$ & $\begin{array}{l}\text { Online PD course, webinars and } \\
\text { Community of Practice }\end{array}$ & Externally Supported \\
\hline 2 & $\begin{array}{l}\text { Real World } \\
\text { Practice }\end{array}$ & $\begin{array}{c}\text { Develop STEM-professional } \\
\text { partners }\end{array}$ & \\
\hline 3 & $\begin{array}{l}\text { Real World } \\
\text { Practice }\end{array}$ & $\begin{array}{c}\text { Implement pre-created library } \\
\text { program series }\end{array}$ & $\begin{array}{l}\text { Engaged } \\
\text { (engaged) }\end{array}$ \\
\hline 4 & $\begin{array}{l}\text { Concept-based } \\
\text { Learning }\end{array}$ & $\begin{array}{c}\text { Online PD course, webinars and } \\
\text { Community of Practice }\end{array}$ & \\
\hline 5 & $\begin{array}{l}\text { Real World } \\
\text { Practice }\end{array}$ & $\begin{array}{c}\text { Contribute to development of new } \\
\text { program materials }\end{array}$ & \\
\hline 6 & $\begin{array}{c}\text { Real World } \\
\text { Practice }\end{array}$ & $\begin{array}{c}\text { Implement new library program } \\
\text { series }\end{array}$ & $\begin{array}{l}\text { Self-efficacy } \\
\text { (self-efficacy) }\end{array}$ \\
\hline 7 & Application & $\begin{array}{c}\text { Develop a new library program } \\
\text { series }\end{array}$ & $\begin{array}{l}\text { Peer/Self-supported } \\
\text { Peer/Self-supported }\end{array}$ \\
\hline
\end{tabular}

Central to the project is a website that serves as a digital platform for the librarians (and their science partners-a local individual with some scientific expertise, possibly, but not necessarily a professional scientist, present to help provide domain-specific information and to act as a partner to the librarian in encouraging conversation and questions). Therein the participants are able to engage in professional development, share ideas in threaded discussions, and access program materials. In short, online communication is crucial to the success of the PTL initiative.

In what follows, we first give a brief introduction to the PTL programming. We then discuss the online resources comprising the scaffolded support of the librarian professional development. Included are some of the major takeaways from our evaluation (conducted by Goodman Research Group) of the materials (the final report will be published on informalscience.org). Anticipated subsequent analyses from coming summative evaluations are outlined in a brief conclusion.

\section{DESIGN OF PUSHING THE LIMITS PROGRAMS}

\subsection{Understanding the Audiences}

Research increasingly documents that an informal STEM learning approach to gaining new knowledge is particularly appealing to adults (Jones et al., 2017; Brookfield et al., 2016; Falk et al., 2012; Fenichel and Schweingruber, 2010). ISL expands on principles of 
adult learning theory, which in practice is characterized by learning that is personalized, self-directed, and voluntary (Brookfield, 1984; Knowles, 1978). In brief, the motivation and readiness to learn for adults is largely based on their life situations. As needs, interests, and problems emerge in their lives, they seek out information to find a solution to a problem, address a need, or satisfy an interest. Adults also bring a wealth of experience to a learning situation. They process new information against this backdrop of personal knowledge and use their past experiences to aid their learning. The catalyst for learning and a continued desire to expand knowledge about a topic tend to be internally generated and grounded in one's social, career, and community roles (Knowles, 1978, pp. 45-49).

Libraries are a natural place to convene learning opportunities for adults. This is especially true in rural communities, where there may be few public spaces and resources designed for gathering and learning (Berry, 2009; Vavrek, 2008). STEM-related subject matter is a great resource for materials and topics for adults interested in learning about new ideas. Librarians are always interested in expanding the services they can provide to their communities (Pollack, 2002), and Pushing the Limits takes advantage of this conjunction of aligned interests.

\subsection{The Rural Library Program Experience}

The Pushing the Limits program resources, which are accessed on the website and used by librarians along with local science partners, apply aspects of ISL best practices by focusing on broad themes and topics that have the potential to connect with community members on multiple levels. The programming is targeted-both in terms of presentation and outreach—to an audience that ordinarily will not identify as "STEM-interested," with the intent of bringing new audiences into the library and to participate in informal STEM learning experiences. Each library program includes a shared book reading, and then a face-to-face experience in the library that includes one to two videos and discussion. The videos capture the real-life experiences of individuals or families who are using science in their everyday lives, and the books are selected for their general appeal and potential relevance to adult audiences. Programs are marketed as much as community gettogethers as they are learning experiences. At each program, the librarian and a science partner facilitate a discussion, building on participants' comments, ideas, and questions. The programs are not meant to impart specific facts and data; rather, the goal is to generate discussion and build understanding (and STEM interest).

Each program focuses on a specific theme, and audience engagement is promoted through the use of complementary materials. One short video (10-15 minutes) covers basic STEM concepts that are relatable to a broad audience and are introduced in a human-interest context by following the experiences of an individual or family as they use 
science-even though they themselves are not "scientists" (in the sense in which people traditionally imagine scientists). These are "real people using real science" in their everyday lives, much as the audience does-and this "relatable" context aims to foster a sense among the participants that science is relevant to their lives and may in fact be a part of their everyday activities. The video is paired with a book that offers a perspective about the theme. The librarian and science partner are encouraged to select a book that they think will resonate with their community and addresses local or regional STEM issues. In addition to the program videos and lists of recommended books, each participating librarian is provided a set of suggested discussion questions to foster discussion and community engagement around STEM opportunities and challenges. Collaborations with community groups and organizations are also encouraged as a way to connect program participants with local initiatives and resources.

The Pushing the Limits program series currently has eight themed programs: Nature, Survival, Knowledge, Connections, Tradition, Heritage, Motion, and Transformation. Nature, for example, considers what it means for something to be "natural"-whether in the environment or in ourselves-and poses provocative questions for discussion: If the environment changes, or we change, when is that change no longer part of what is "natural"?, and Is there such a thing as "human nature" and can we escape it, or even shape it? In the program video, the audience sees Cameron Clapp, a triple amputee, and use of new technologies that push the limits of what it means to be human. The recommended book for the program is T.C. Boyle's When the Killing's Done, a fictionalized account of the true story of an effort to eradicate a colony of rats that had overtaken the Catalina Islands off the coast of California. The media materials each ask (in their own way) the participants to consider "what is natural?" and if we can change things, "should we?"

To give just one more example, in the program Transformation, the concept of transformation is explored as a universal experience-the child becomes an adult; we meet people and they change our lives and sometimes we change theirs. The program video follows the life of Heather Doyle, who grew up in a "DIY" family in rural Wisconsin. She has become an artist, teacher, and social activist, and finds ways to use her love of blacksmithing to transform not only metal but also to transform her own life as well as the lives of people around her. Through the adaptation and new customizations of the programs that the librarian-scientist teams have hosted, the books used in the Transformation programming have included Barbara Kingsolver's Flight Behavior; David McCullough's The Wright Brothers; How Enlightenment Changes Your Brain: The New Science of Transformation by Andrew Newberg and Mark Robert Waldman; and Hope Jahren's Lab Girl. These fully supported programs have proved to be quite successful in 
attracting new audiences to library programs and fostering rich discussion around STEM topics and issues (Gareis et al., 2014).

\section{SCAFFOLDING, SUPPORT, AND ONLINE PROFESSIONAL DEVELOPMENT}

With the rollout in 2012 of the initial Pushing the Limits programming, a baseline survey of participating librarians (74 libraries from 34 states with a response rate of 93\%) showed that only a quarter had experience with adult STEM-related programming and less than half felt significant comfort in facilitating science programming (Gareis et al., 2014). For the current cohort, the project team has developed a more targeted, detailed measure of science self-efficacy (see Verbeke et al., in press), which is being administered at multiple time points to track changes as librarians move through the training. An overarching goal of the subsequent Pushing the Limits project (2015-current) has been to move librarians from their role as an ISL event "convener" (i.e., using "program-in-a-box" materials and producing a successful adult-oriented ISL event) to that of a "developer" (i.e., creating and organizing, from start to finish, a successful adult-oriented ISL event) (Fig. 1).

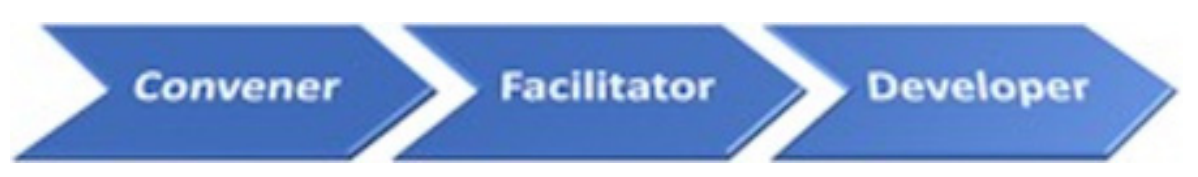

FIG. 1: Visualization of the convener to developer pathway

The process for reaching this goal has been to facilitate librarians' competency development through sequenced experiences-providing materials and frequent project staff suggestions at the start to enable the convening and promotion of a four-part program series and then, step by step, reducing material support as librarians shaped and then developed new programs more independently. Online support systems were and are crucial to the success of this approach.

To be a little more specific, the online learning consists of twelve modules that cover four main content areas: (1) understanding informal STEM learning, (2) building the capacity of libraries as community resources for STEM learning, (3) initiating library partnerships with community organizations and institutions, and (4) fostering community engagement and discussion through STEM programming. The professional learning modules integrate a range of tasks and approaches, requiring the watching of short skills-based videos, reading of online material, and completing planning and application activities. An online discussion forum and interactive webinars supplement the asynchronous learning modules. Rather than presenting the twelve learning modules one right after another, a set 
of related modules is presented and the librarians then apply what they have learned by offering a series of Pushing the Limits programs in their community. This scaffolded learning approach progresses over a 21/2-year period, as outlined in Table 2.

TABLE 2: The scaffolded learning approach

Building Foundations for Informal STEM Learning

Online Learning

- Unit 1: Adult STEM Programs in Your Library

- Unit 2: What is Informal STEM Learning (ISL)?

- Unit 3: Libraries as Resources for ISL

- Unit 4: Selecting and Working with Your Science Partner

- Unit 5: Planning and Marketing Your ISL Programs

- Unit 6: Fostering Engaging ISL Program Discussions

Timespan: 3 months

Public Programs [fully supported]

(Project provides program videos, suggested book, and discussion questions.)

- Pushing the Limits of Nature

- Pushing the Limits of Connection

- Pushing the Limits of Survival

- Pushing the Limits of Knowledge

Timespan: 6 months

\section{Introduction to Advancing Leadership in Informal STEM Learning}

Online Learning

- Introduction to Advancing Leadership in Informal STEM Learning

- Unit 7: Focusing on STEM Concepts

- Unit 8: Public Engagement with STEM

Timespan: 1.5 months

Public Programs [reduced supported]

(Project provides program videos, suggested book, and discussion questions.)

- Pushing the Limits of Transformation

- Pushing the Limits of Tradition

Timespan: 5 months 
Online Learning

- Unit 9: Expanding and Enriching Library STEM Programs

- Unit 10: Library Leadership and Community Collaboration

Timespan: 1 month

Public Programs [support reduced further]

(Project provides program videos, suggested book, and discussion questions.)

- Pushing the Limits of Motion

- Pushing the Limits of Heritage

Timespan: 4 months

Online Learning

- Unit 11: Community Analysis of STEM Needs and Interests

- Unit 12: Sustaining STEM Programming

Timespan: 1 month

Public Programs [librarian-initiated support through online forum]

- Librarians design and offer two adult STEM programs.

Timespan: 6 months

Online Learning

- Online forum discussion: Best Practices for Adult STEM Programming in Rural Public Libraries.

Timespan: 1 month

(No online learning or project-required STEM programming)

Timespan: 4 months

Key to the project is a strong research arm investigating the effectiveness of the project's professional development in building librarians' science self-efficacy. $\ddagger$ Early research results show promise. What follows is a discussion of the survey methods and our initial findings.

\section{METHODS}

Rural librarians were invited to participate in the project through state and national e-mail lists, at conventions, and via state libraries, continuing education venues, and library consortia. Over 300 libraries applied, and 110 were selected, with the goal of achieving a representative sample of U.S. rural librarians in terms of geographic distribution, library size, and socioeconomic diversity; libraries were also chosen for their ability to fulfill the 
needs of the grant. The initial sample of librarians was primarily female (88\% of the 104 who completed surveys at baseline).

\section{MEASURES}

Of interest for the PTL project is a more focused notion of science self-efficacy than presented above and defined by Verbeke et al. (see Verbeke et al., in press) as "how comfortable an individual is carrying out science activities, including talking about, participating in, and understanding science." Minimal science self-efficacy will enable a librarian to be a convener of STEM-related events (like the fully supported PTL events). The PTL project, however, aims to move participants in a positive direction along the convener-developer continuum. See Appendix in Verbeke et al. (in press) for the convener-to-developer continuum and the self-efficacy scale items, along with mean scores for participating librarians before starting the scaffolded professional development.

In this article, we report data from surveys administered at three time points: (1) Baseline: Before beginning the online professional development, 104 of the 110 librarians (95\%) completed a survey; (2) Post-Foundations Professional Development: After completing the first six units of professional development, 93 of 104 remaining librarians (89\%) completed a survey; and (3) Post-Program Series 1: After holding the first four programs in their communities, 79 of the 99 remaining librarians (80\%) completed a survey. (As reflected in the decreasing denominators, there has been a small amount of attrition over time in the number of libraries participating in the project.) As librarians go through the Advanced Leadership portion of the training and hold additional programs, they will fill out four additional surveys.

\section{LIBRARIAN ASSESSMENTS OF PROFESSIONAL DEVELOPMENT}

These librarians were not new to online professional training; 96\% (of 93 responding to the post-professional development survey) had at least one previous online training experience, and $71 \%$ had three or more. Almost all (99\% of 93) considered themselves at least "somewhat" computer savvy, and 63\% considered themselves "very" or "extremely" computer savvy.

When asked on the post-professional development survey about the online delivery platform (webinars, website, and discussion board), most of the 94 librarians who responded to this item "agreed" or "strongly agreed" that they could confidently use the tools provided on the project website, including the discussion board (87\%) and that the online format (webinars, website, and discussion board) was a fitting method of delivery for this professional development (84\%). Similar percentages endorsed the website $(83 \%)$ and discussion board (82\%) as a place they would go for information or advice related to facilitating adult science programming. (The top resource as envisioned in the project 
design was a local scientist.) Averaging across the six units of professional development, $71 \%$ found each unit "very" or "extremely" helpful.

In terms of the most useful components of the professional development, $78 \%$ rated the online videos as "very" or "extremely" useful. Just under two-thirds (64\%) gave similarly high ratings to the online discussion board. Fewer librarians-56\%-gave similarly high ratings to the interactive webinars with other librarians, although $13 \%$ reported not having participated in the webinars. These numbers are perhaps reflective of the convenience of asynchronous ("on-demand") media, especially for working professionals.

Once librarians had delivered the first series of four adult programs in their libraries, they reflected back on the extent to which their professional development to date had prepared them to plan and facilitate the programming. The majority felt "prepared" or "very prepared" to:

- understand informal science learning (88\%),

- engage audience members (87\%),

- co-facilitate informal science conversations (86\%),

- support audience learning (86\%),

- coordinate and plan for the program series (80\%),

- work effectively with their science partners to co-facilitate programs (79\%), and

- promote the programs (70\%).

After conducting the first program series, most librarians reported that their professional development to date had prepared them "quite a bit" or "a great deal" to facilitate other adult informal science learning programming (88\%), lead new informal science learning programming $(81 \%)$, develop the library to serve as a resource for science information in their communities (76\%), and develop new adult informal science learning programming (75\%).

Regarding the discussion community specifically, 78\% "agreed" or "strongly agreed" that it had been useful in planning and delivering the first four programs, and $70 \%$ were similarly positive about its role in helping them feel connected to a larger professional community.

\section{LIBRARIANS BUILDING THEIR CAPACITY AS SCIENCE PROGRAM DEVELOPERS}

A repeated-measures ANOVA showed that across the three time points, librarians showed significant gains in feelings of science self-efficacy across the three time points; $F$ $(1.68,112.67)=5.59, p=0.008$, with a partial eta-squared of 0.077 , indicating a medium- 
sized effect. Marginal means show that librarians moved from an average score of 29.84 to 28.91 to 33.72 on a scale from -72 to +72 . Planned comparisons indicate that the significant jump occurred after librarians completed both the professional development and the programming. For example, there appeared to be upward trends in being comfortable answering questions even in areas where they lack deep content knowledge, enjoyment of working with scientists and acquiring new science skills, and comfort leading science programs for adults. They also showed steadily decreasing agreement with negative statements about their role being simply to ensure attendance at events, being more comfortable with programming for children, and thinking only experts should be leading adult educational programming.

Not surprisingly, librarians also made statistically significant progress along the convener -developer continuum; $F(2,128)=18.42, p=0.000$, with a partial eta-squared of 0.224 , indicating a large effect. Planned comparisons showed a significant change from baseline to after the first six units of professional development, with a marginally significant further increase after presenting the first four programs. Marginal means show that librarians moved from an average score of 5.17 to 5.95 to 6.37 on a 9-point scale from convener (1) through facilitator (5) to developer (9). Thus, the Foundations portion of the Rural Gateways program was quite successful in moving participating librarians closer to the "developer" end of the continuum.

\section{CONCLUSION}

Our findings support the claim that an online delivery of professional development materials is very effective in our scaffolded effort to build skills (and we hope, confidence) in our librarian participants as they move along the convener-developer continuum. Participants take combined professional development and programming surveys after every two professional development units/two programs as they progress to more and more independent programming. In subsequent analyses, we will be able to see what the advanced professional development adds over and above the foundational professional development in terms of science self-efficacy and moving them along the developer continuum.

\section{REFERENCES}

American Library Association (ALA), State of America's Libraries Report 2017, American Library Association, April 2, 2017. Retrieved November 30, 2018, from http://www.ala.org/news/state-americas-libraries-report-2017.

Bandura, A., Chapter 14: Guide for Constructing Self-Efficacy Scales, in F. Pajares and T. Urdan, Eds., Self-Efficacy Beliefs of Adolescents, pp. 307-337, Greenwich, CT: Information Age Publishing, 2006. 
Beed, P., Hawkins, M., and Roller, C. Moving Learners Towards Independence: The Power of Scaffolded Instruction, Reading Teacher, vol. 44, no. 9, pp. 648-655, 1991.

Berry, J., The Bigger They Come..., Library J., vol. 134 , no. 8, p. 8, 2009.

Brookfield, K., Tilley, S. and Cox, M., Informal Science Learning for Older Adults, Sci. Commun., vol. 38 , no. 5, pp. 655-665, 2016.

Brookfield, S., Adult Learners, Adult Education, and the Community, New York: Teachers College, Columbia University, 1984.

Falk, J.H., Randol, S., and Dierking, L.D., Understanding the Informal Science Education Landscape: An Exploratory Study, Public Understanding Sci., vol. 21 , no. 7, pp. 865-874, 2012.

Fenichel, M. and Schweingruber, H.A., Surrounded by Science: Learning Science in Informal Environments, Board on Science Education, Center for Education, Division of Behavioral and Social Sciences and Education, Washington, DC: The National Academies Press, 2010.

Gareis, K.C., Lukasiewicz, E., and Goodman, I.F., Pushing the Limits: Making Sense of Science: Summative Evaluation, Cambridge, MA: Goodman Research Group, 2014.

Gibson, S. and Dembo, M., Teacher Efficacy: A Construct Validation. J. Ed. Psychol., vol. 76 , pp. 569-582, 1984.

Jones, M.G., Corin, E.N., Andre, T., Childers, G.M., and Stevens, V., Factors Contributing to Lifelong Science Learning: Amateur Astronomers and Birders, J. Res. Sci. Teaching, vol. 54 , no. 3, pp. 412-433, 2017.

Knowles, M., The Adult Learner: A Neglected Species, 2nd edition, Houston: Gulf Publishing Co., 1978.

McKinnon, M. and Lamberts, R., Influencing Science Teaching Self-Efficacy Beliefs of Primary School Teachers: A Longitudinal Case Study, Int. J. Sci. Ed., Part B, vol. 4 , no. 2, pp. 172-194, 2013.

National Science Foundation (NSF), Public Libraries and STEM: A National Conference on Current Trends and Future Directions, Denver, Colorado, USA, August 20-22, 2015. Retrieved November 30, 2018, from https://www.Ipi.usra.edu/education/ stemlibraryconference/.

Palincsar, A.S., The Role of Dialogue in Providing Scaffolded Instruction, Ed. Psychol., vol. 21 , nos. 1 and 2, pp. 73-98, 1986.

Pollack, M., Democratizing Human Genome Project Information: A Model Program for Education, Information and Debate in Public Libraries, ERIC Document Reproduction Service no. ED 472 874, 2002. 
Riggs, I. and Enochs, L., Toward the Development of an Elementary Teacher's Science Teaching Efficacy Belief Instrument, Sci. Ed., vol. 74 , pp. 625-638, 1990.

Tschannen-Moran, M. and Hoy, A.W., Teacher Efficacy: Capturing an Elusive Construct, Teaching Teacher Ed., vol. 17 , pp. 783-805, 2001.

Tschannen-Moran, M., Hoy, A.W., and Hoy, W.K., Teacher Efficacy: Its Meaning and Measure, Rev. Ed. Res., vol. 68 , no. 2, pp. 202-248, 1998.

Vavrek, B., Looking to the Future, Rural Libraries, vol. 28 , no. 2, pp. 7-8, 2008.

Verbeke, M., Falk, J.H., Brown, K., and Meier, D., A Study of Rural Librarians' Self-efficacy in Facilitating and Developing Adult Science Programs, Library Quarterly (in press).

\section{APPENDIX A: CONVENER-TO-DEVELOPER CONTINUUM}

Where would you place yourself along the following continuum from Science Program Convener to Science Program Developer, with a midpoint of Science Program Facilitator?

\begin{tabular}{|ccc|}
\hline Baseline & Post-Foundations PD & Post-Program Series 1 \\
$(N=111)$ & $(N=93)$ & $(N=75)$ \\
5.41 & 5.86 & 6.35 \\
\hline
\end{tabular}

Scale: 1 = Convener, 5 = Facilitator, 9 = Developer .

\section{A.1 Science Self-Efficacy}

Part I: Whether you've acted in the role of a program leader or not, please rate your agreement with the following statements related to facilitation of adult programs.

\begin{tabular}{|c|c|c|c|}
\hline & Baseline & $\begin{array}{l}\text { Post- } \\
\text { Foundations } \\
\text { PD }\end{array}$ & $\begin{array}{l}\text { Post- } \\
\text { Program } \\
\text { Series } 1\end{array}$ \\
\hline & $\begin{array}{c}(N=112 \\
-113)\end{array}$ & $(N=94)$ & $(N=72-73)$ \\
\hline \multicolumn{4}{|l|}{ Positively Framed Items } \\
\hline $\begin{array}{l}\text { 1. I like being up at the front } \& \text { being in charge of } \\
\text { adult groups. }\end{array}$ & 5.23 & 4.77 & 5.11 \\
\hline \multirow{2}{*}{$\begin{array}{l}\text { 2. Even leading an activity where I lack deep } \\
\text { content knowledge, I am comfortable answering } \\
\text { adult patrons' questions. }\end{array}$} & 4.71 & 4.68 & 4.93 \\
\hline & 6.03 & 6.00 & 6.08 \\
\hline
\end{tabular}


3. I believe I have something to offer my community, which comes through when I create adult programming.

4. I see facilitating adult programs as a good way to have an impact in my community.

$\begin{array}{lll}6.46 & 6.26 & 6.36\end{array}$

5. I'm a vocal advocate of library outreach in my community.
6.20
6.23
6.44

6. Unless an adult patron explicitly asks for help, I tend to let patrons explore the library by themselves.

\section{Negatively Framed Items}

7. I find it difficult to get adult patrons engaged in discussion.

8. The librarian's main job in adult programming is ensuring that people show up for the program.

$\begin{array}{lll}3.57 & 3.54 & 3.07\end{array}$

9. I am not an expert \& prefer to stay in the background.

10. I am more comfortable working with children than with adults.

$\begin{array}{lll}3.28 & 3.16 & 3.10\end{array}$

11. I find it difficult to make activities meaningful for adults.

$\begin{array}{lll}3.03 & 3.10 & 2.92\end{array}$

12. I think leading adult educational programs should be the job of experts, specialists.

Scale: 1 = Strongly disagree, 2 = Disagree, 3 = Somewhat disagree, $4=$ Neither agree nor disagree, 5 = Somewhat agree, $6=$ Agree, 7 = Strongly agree.

Part II: To what extent do you agree with the following statements about your relationship with science?

$\begin{array}{ccc}\text { Baseline } & \begin{array}{c}\text { Post- } \\ \text { Foundations } \\ \text { PD }\end{array} & \begin{array}{c}\text { Post- } \\ \text { Program } \\ \text { Series 1 }\end{array} \\ (N=104) & (N=92-93) & (N=70-71)\end{array}$

Positively Framed Items

13. I like to learn about science.

6.18

5.88

6.35

14. If I am asked to provide assistance on a science subject that is outside of my general knowledge, I can usually find the information for 6.05 5.99 6.25 my patrons. 


\begin{tabular}{|llll|}
$\begin{array}{l}\text { 15. I enjoy working with scientists. } \\
\text { 16. I enjoy acquiring new science skills. }\end{array}$ & 5.53 & 5.75 & 6.18 \\
$\begin{array}{l}\text { 17. I am interested in designing science } \\
\text { programs for adult patrons. }\end{array}$ & 6.31 & 5.92 & 5.97 \\
$\begin{array}{l}\text { 18. I am comfortable leading science programs } \\
\text { for adults. }\end{array}$ & 5.05 & 5.10 & 5.73 \\
\multicolumn{1}{|c}{ Negatively Framed Items } & & & 4.31 \\
$\begin{array}{l}\text { 19. I'm often afraid I don't know as much about } \\
\text { science as people think I do. }\end{array}$ & 3.99 & 3.72 & 1.73 \\
$\begin{array}{l}\text { 20. I find science to be boring. } \\
\text { 21. I get tense \& nervous when adult patrons } \\
\text { ask me to support their science interests. }\end{array}$ & 2.31 & 1.93 & 2.58 \\
$\begin{array}{l}\text { 22. I am comfortable leading science programs } \\
\text { for children but not adults. }\end{array}$ & 2.92 & 3.12 & 2.86 \\
$\begin{array}{l}\text { 23. I feel embarrassed when I can't absorb } \\
\text { science concepts. }\end{array}$ & 3.59 & 3.66 & 3.38 \\
$\begin{array}{l}\text { 24. Even with good professional training, I am } \\
\text { not sure I would be able to lead a science- } \\
\text { learning program for adult patrons by myself. }\end{array}$ & 2.04 & 2.52 & 2.38 \\
\hline
\end{tabular}

Scale: 1 = Strongly disagree, 2 = Disagree, 3 = Somewhat disagree, $4=$ Neither agree nor disagree, 5 = Somewhat agree, 6 = Agree, 7 = Strongly agree.

\section{NOTES:}

† "Pushing the Limits: Building Capacity to Enhance Public Understanding of Math and Science through Rural Libraries," NSF DRL 1010577 (2010-2015); "Rural Gateways: Fostering the Development of Rural Librarians as Informal Science Facilitators,” NSF DRL 1515241 (2015-2020 - projected).

\$ This is being led by The Institute for Learning Innovation of Portland, Oregon. 